\title{
CREDIT RATING AGENCIES AND THEIR EFFECTS: AN ANALYSIS ON BALKAN COUNTRIES
}

\author{
Nuh Ekrem YILDIRIM" ${ }^{1}$, Salim ÜRE2 ${ }^{2}$, Çağatay KARAKÖY³ \\ ${ }^{1}$ Akdeniz University, Korkuteli Vocational School, Department of Finance, Antalya, Turkey, \\ nuhekremyildirim@hotmail.com \\ 2 Sivas Cumhuriyet University, Faculty of Economics and Administrative Sciences, Department of \\ International Trade and Logistics, Sivas, Turkey, salimure92@gmail.com \\ ${ }^{3}$ Sivas Cumhuriyet University, Faculty of Economics and Administrative Sciences, Department of \\ International Trade and Logistics, Sivas, Turkey, ckarakoy@cumhuriyet.edu.tr
}

\begin{abstract}
The financial structure in the world has become more complex with the increase in global capital movements. For this reason, credit rating agencies have emerged as an important component of the financial structure. Standard and Poors, Moody's and Fitch are the three most important companies in this market. The grades given by these institutions highly affect the economic situation of the countries. In this study, information is given about credit rating agencies and it is aimed to measure the effect of the points given to countries by Standard and Poors, Moody's and Fitch, which are the most important of these institutions, on the economy. For this purpose, the effect of credit scores on the economic growth of Balkan countries except Kosovo was analyzed using panel data analysis method. In addition, unemployment, inflation, current account balance and budget balance data were included in the analysis. The findings obtained show that credit scores have an effect on the economic growth of countries.
\end{abstract}

Keywords: Credit Rating Agencies, Sovereign Rating, Balkan Countries, Turkey

Original scientific paper

Received: 25.09.2021

Accepted: 11.10.2021

Available online: 20.10 .2021

\section{Introduction}

With the increase in the circulation of production factors between countries, financial integration has started to gain importance. Although financial integration has been a process that made countries closer to each other, it is necessary to know the different economic and financial structures of the countries well. Because most countries, especially the developing countries, need funds in a complex financial structure. This situation raises the question of how and in what way a country in need of funds can borrow money. Of course, funds may be needed not only by countries but also by many groups such as public institutions, financial and non-financial private sector organizations.

Different political, economic and cultural structure and so forth, is not an easy process to ensure a healthy flow of information between the groups that demand and supply funds for

\footnotetext{
${ }^{*}$ Corresponding author
} 
various reasons. Institutions called Credit Rating Agencies (CRA) undertake the task of eliminating the information asymmetry problem between these groups that demand and supply funds. CRAs, whose origins date back to the 19th century, guide investors by acting independently by measuring credit risk. These CRAs, which also affect the markets by grading countries, have an undeniable power. Because a country with a low credit rating finds debt at high interest rates, at the same time it becomes difficult for foreign capital to enter these countries and investments fall. Although there are many CRAs today, Standard and Poors (S\&P), Moody's and Fitch are the 3 major credit rating agencies that dominate the world markets.

The aim of this study is to provide information about the content of credit rating agencies and to make a general assessment to examine their effects on the economy of countries. Within this context, the definition and evaluation process of the credit rating concept within the framework of its historical development are given, and information is given about the measurement methods of these institutions and the economic effects of the rating they give. After examining the data of the Balkan countries, excluding Kosovo, the historical development of the notes given by the CRAs to Turkey is mentioned. Lastly, in order to examine the impact of credit ratings on the economy of countries, panel data analysis was applied to determine the relationship between the said ratings and the real growth rate, which is one of the main indicators of the economy. In addition, unemployment, inflation, current account balance and budget balance variables were added to the analysis as control variables.

\section{The Concept of Credit Rating and Its Historical Development}

When credit ratings began in the early 20th century by independent rating agencies in the United States, bond and capital markets had already existed for at least 300 years, Since most businesses were local in the early years of US history, transactions took place between people who knew each other. As the scope of transactions expands geographically, information needs about businessmen and customers have started to increase. While letters of recommendation from respected people such as bankers and lawyers were sufficient for transactions, the expansion of American business in the 1830s created the need for a new institution specializing in credit reporting. In 1841, Levis Tappan decided to specialize in the drapery and silk trade in New York, keeping records on the creditworthiness of customers. Tappan, who founded the Mercantile Agency, established a wide network and sold information about the commercial credibility of businesses all over the USA to customers (Sylla, 2002: 2-7).

The "Manual of Industrial and Miscellaneous Securities", published by Moody's in 1900, was the first study on the country's credit rating risk. A list of sovereign bonds has been created in this report, data were provided but it does not involve any ratings. Basically, information about companies, public institutions, railway companies and foreign governments has been compiled. Railroad companies were perhaps the world's first large businesses in the United States, probably also in the World. John Moody made the first rating transactions on US railroad bonds in 1909.Later, Poor entered the bond rating business in 1916, followed by Standard company in 1922 and Fitch company in 1924.The Poor company merged with another rating company, Standard, and established Standard and Poors in 1941.After the collapse of the stock markets in 1929, CRAs started to decline and started to lose their importance with the public offering of companies. In 1975, the US Securities and Exchange Commission (SEC) defined 3 major CRAs (Moody's, Standard and Poors (S\&P) and Fitch) as nationally recognized credit rating agencies (Mullard, 2012: 86-87; Sylla, 2002: 8-9).

Although credit rating agencies that emerged in the USA in the early 1900s have been an American phenomenon for most of the 20th century, they gained a global dimension in the 1970s 
with the development of capital markets. Ratings, which play a role in the regulation of American financial markets, have expanded over time. In the last 100 years, the application of rating procedures in large amounts of borrowing and investment decisions has become widespread with credit rating agencies around the world (Levich et al. 2002: 1-2). The credibility of the countries should be questioned by the investors in making these huge borrowing and investment decisions. This illustrates the need for organizations that require good expertise.

In the 1960s, the most important visitor to a developing country was the international development agency, the US foreign aid agency, while in the 1970s and 1980s it was the IMF, which aimed to restructure the economy for these countries. The most important visitor to these developing countries in the 1990s was Moody's Investor Services. Since we now live in an age where governments basically do not have two nickels to rub together, countries; must either supply savings at home or attract investors from the world's largest bond markets in order to develop. Moody's is a rating agency that tells where investors can use their funds by telling which country bonds are reliable/unimportant. This makes Moody's strong. In fact, we can say that we live in almost two worlds of power: the USA and Moody's. The USA can flatten and destroy a country with bombs, while Moody's can destroy a country by downgrading it (Friedman, 1995). Especially within the last 30 years, CRAs have had significant effects that can affect the conditions of developing countries. The increase in private capital flows and financial aid is an important factor in this. This is due to limited information and lack of transparency in developing countries. Developed countries force many institutional investors to hold securities above a certain threshold. When a country downgrades from an investment grade to a speculative level, it imposes significant costs on the country (Tennant et al. 2016: 2). Countries that borrow at high costs become vulnerable to external shocks and their vulnerability is increasing.

Moody's, along with its main rivals Standard and Poors (S\&P) and Fitch, has managed to bring national governments, including the United States, to heel (The US Should Let Its Credit Rating Be Downgraded-and Shrug).Considering the macroeconomic effects of fluctuations in global liquidity volume on countries, it is understood that the three main CRAs can have a say at least as much as country administrations and these institutions will maintain their importance.

Although there are many definitions of the concept of credit rating, there is no standard definition. An association of rating agencies has not yet been established. For instance, the US Securities and Exchange Commission (SEC) explains credit rating concept as; "the opinion of a rating agency on the credibility of a security or debt, a certain company, as of a certain date". According to the European Commission, this concept is to express an opinion on the creditworthiness of a particular issuer or financial instrument. While these definitions look at the concept of credit rating from a comprehensive perspective, each rating agency has its own specific definition (Langohr et al. 2008: 23-24). In general terms, the definitions of the three major credit rating agencies regarding this concept are as follows:

According to S\&P, credit rating concept: a forward-looking view regarding the fulfillment of certain financial obligations by a debtor (S\&P Global Rating Definitions, Standard and Poors, 2017: 2).

According to Moody, the concept of credit rating; public institution is a forward-looking view on the credit risk of financial assets of non-financial / financial institutions based on financial instruments (Rating Symbols and Definitions, Moody's Investor Services, www.moodys.com)

According to Fitch, the concept of credit rating is an opinion on the ability of an organization to fulfill its financial commitments such as capital and interest (Rating Definitions, Fitch, https://www.fitchratings.com/site/definitions). 
Considering the definitions of credit rating, it is generally possible for CRAs to express their opinions on financial commitments. Although the opinions of these institutions are not binding, they highly affect the credibility of the rated countries/institutions. Market actors also shape their behavior according to the views given.

Table 1. Percentage of Credit Rating Agencies by Categories (As of December 31, 2019)

\begin{tabular}{lllll}
\hline Organization & $\begin{array}{l}\text { Financial } \\
\text { Institutions }\end{array}$ & $\begin{array}{l}\text { Insurance } \\
\text { Companies }\end{array}$ & $\begin{array}{l}\text { Issuer } \\
\text { Companies }\end{array}$ & $\begin{array}{l}\text { Asset- } \\
\text { Backed } \\
\text { Securities }\end{array}$ \\
\hline S\&P & 37.2 & 31.7 & 46.0 & 24.6 \\
Moody's & 23.5 & 11.9 & 25.1 & 33.3 \\
Fitch & 23.3 & 15.8 & 16.5 & 21.9 \\
Other* & 16.0 & 40.6 & 12.4 & 20.2 \\
Total & 100 & 100 & 100 & 100 \\
\hline
\end{tabular}

* In this report, A.M. Best, DBRS, EJR, HR Ratings, JCR, KBRA, Morningstar form the other credit rating agencies.

Source: Insecurities and Exchange Commission, 2020: 11

Table 1 shows the percentage of total ratings made by major credit rating agencies in the global financial system. Accordingly, Standard and Poors alone makes about half of the total rating worldwide (50,1 percent), Moody's ranks second with 32,0 percent, and Fitch ranks third with 13,0 percent. The rating rate of other CRAs remains at a very low level with a rate of 4,9 percent. The 3 big CRAs, which carry out approximately 95 percent of the total rating, maintain their influence and importance in the financial system.

Rating revenues obtained by CRAs usually consist of fixed fees from companies and revenues collected at the time of a bond's initial rating. There are also revenues from analysis sales and other services provided to investors (Becker et al. 2011: 500).

Table 2. Total Percentage of Credit Rating Agencies Revenues

\begin{tabular}{lllll}
\hline Credit Rating Agency & $\mathbf{2 0 1 6}$ & $\mathbf{2 0 1 7}$ & $\mathbf{2 0 1 8}$ & $\mathbf{2 0 1 9}$ \\
\hline S\&P, Moody's and Fitch & 94.4 & 94.1 & 93.5 & 93.3 \\
Other & 5.6 & 5.9 & 6.5 & 6.7 \\
Total & 100 & 100 & 100 & 100 \\
\hline Source: U.S. Securities and Exchange Commission, 2020: 14.
\end{tabular}

Table 2 shows the total percentage of revenues of major CRAs in the financial system. As can be seen from the table; the 3 big CRAs earn high revenues, with $93,3 \%$ of their total rating revenues.

\section{Evaluation Process of Credit Rating Agencies}

The CRA industry, which is fully integrated into the financial system involves complex relationships between securities issuers, securities regulators, individual and large-scale institutional investors, and credit rating agencies that rate securities.

The characteristics of the CRA industry are as follows:

- The CRAs are private organizations under government oversight (SEC in the US example). 
- They have a great influence on financial markets by rating countries and large companies based on advisory recommendations.

- The investors believed that CRAs were reliable and authoritative in rating.

- Historically, SEC has approved some rating agencies and later required financial institutions to use these CRAs to make investment decisions.

- CRAs are generally referred to as organizations where, at least in part, the subprime economic crisis resulted from high rates of mis-rating.

- The biggest criticism of economic bankruptcy is that CRAs provide their own interests rather than correctly rating the interests of investors (Scalet et al. 2012: 479482).

In the CRA sector, which is in a complex network of relations, even though both in the qualitative and quantitative evaluation process of companies, municipalities and so forth, differs, they have a similar approach at the base.

Companies that are subject to the evaluation process for the first time hold a meeting with the officials of the rating agencies regarding the information needed. In this context, it is stated that the evaluation process includes the following information:

- Legal advice on specific issues

- Qualitative data on management, policy, business overview, accounting practices, etc., by the issuer

- Qualitative data collected by the rating agency on issues such as the competitive situation, the future of the industry, and the economic environment.

- Quantitative data provided by the issuing company regarding its own financial situation

- Quantitative data collected by the rating agency on the industry, competitors and economy

Rating agencies are mostly interested in cash flow related data on debt obligations. They want to know how much liquidity power the company can have. Therefore, fluctuations in cash flow to the business will be significant. It may also include 5-year financing projections, including income statements and balance sheets, analysis of capital expenditure plans, financing alternatives and contingency plans. Issuers also on policy choices and strategic plans;

- Information about the company and other organizations

- Outline of corporate strategy or philosophy

- State of the business, including competitive situation, production capacity, distribution and marketing network

- Financial management and accounting policies, whether they use generally accepted accounting principles

- It provides quality information on concerned issues such as country risk, regulations, major investment plans, and so forth. (Sinclair, 2003: 149-150).

Rating agencies form a team to interview issuer companies and prepare reports containing recommendations and justifications. This team presents its final decision on the issuer to senior officials in the rating agency within the framework of confidential information flow. Historically, 
there have been differences between major rating agencies in this regard. For example; While Moody had a more conservative and secretive corporate culture than other competing organizations, it gradually abandoned it in the 1990s.Moody has also published appendices containing financial ratios in the Rating Methodology Handbook published in February 2000. S\&P publishes a number of benchmarks books that contain guidelines on appropriate financial rates for different types of loans. A typical assessment of a country's debt-carrying capacity in the case of a country rating begins with an assessment of the country's current debt burden. S\&P's corporate finance criteria include a section with specific rating ratios. The rating process is usually accepted at the end of the rating committee meeting. Today, there are various rating scales for different financial instruments. Debt ratings on bonds are the most common ones, but S\&P also determined scales for commercial reports, preferred shares, certificates of deposit, money market funds, mutual funds (Sinclair, 2003: 151). In order to overcome the difficulty in measuring such a variety of investment instruments, CRAs should follow current developments well and create their employment accordingly.

Credit rating measures the company's/country's default risk, as well as the borrower's ability and probability of repaying its debt. Rating agencies add value to the market and contribute to reducing information asymmetry by using confidential and proprietary information in the rating process. Companies are ranked according to their relative credit standings and ability to repay their debts, which allows pricing different types of debt. Rating agencies must be careful in awarding high ratings, otherwise it jeopardizes their credibility. Credit rating agencies and ratings in general; plays an important role in today's business environment and financial markets. With the concept of rating, not only stakeholders such as investors and lenders, but also companies benefit in decisions regarding their capital structures. In the studies carried out in this field; it has been revealed that there is a significant relationship between the credit ratings given and various financial ratios (Bjørndalen et al. 2014: 1-2).

The existence of these significant relationships between the credit ratings of S\&P, Moody's and Fitch and the financial and economic data of countries confirms the benefits of these longstanding institutions such as S\&P, Moody's and Fitch. This is due to the simplicity and comparability of the risk assessment systems of the organizations, the analytical power and independence of the institutions based on their intense analytical power. Issuers also request ratings from more than one rating agency in order to expand their pool of investors and create a simple risk assessment. Investors use these data in investment decisions such as securities commerce, hold, so forth. With their shortcomings/flaws, rating agencies have become an increasingly important element of integrated capital markets (Bhatia, 2002: 3). Based on this importance, CRAs constantly monitor countries/institutions in terms of political, economic and financial indicators and convey information to stakeholders.

Credit rating agencies have specialized in analyzing and evaluating the country's issued debt securities and the creditworthiness of the institution. Issuers with lower credit ratings pay higher interest rates with higher premiums than those with higher credit ratings. In addition, ratings determine whether debts and other financial instruments are suitable for portfolios. Credit rating agencies may differ in size and scope (geographical and sectoral), as well as in their methodologies and definitions of default. Regarding the developing countries, the country rating is very important. Country risk is loss of cross-border lending caused by events that are at least under the control of the government, but not strictly under the control of a private business or individual. The rating given to a company or bank in a country cannot exceed the rating of the country. The failure of major rating agencies to foresee the 1997-1998 Asian crisis and the recent bankruptcy of large companies such as Enron, Worldcom and Parmalat has revealed the need to 
examine the rating process and accountability issues of these agencies (United Nations New York and Geneva, 2009:165-166).

In the early 1970s, the business model of major rating agencies also changed. Instead of the 'investor pays' model established by John Moody in 1909, it has transformed into the 'issuer pays' model. In other words, issuers have started to pay the rating agencies for these transactions. The reasons for the change in this business model could not be determined definitively. However, several reasons have been put forward:

- Rating agencies may have feared the consequences of the high-speed photocopy machine, as sales of rating guides may have fallen as investors photocopied the guides from each other.

- The bankruptcy of the Penn-Central railroad in 1970 demonstrated that issuers were low risk and willing to pay rating agencies.

- In order for the issuers to include the assets issued by the financial institutions in their portfolios, it may have been understood by the financial arrangements made by the rating companies that the issuers should have the support of one or more rating agencies.

- Rating companies may have thought-as in many information industries - that the payoff could come from one or both sides.

Whatever the reason is, this change in business model can open the door to potential conflicts of interest. A rating agency may keep the rating of the relevant party high to make the payer happy or to prevent the other rating agency from acquiring customers. As a matter of fact, in October 1995, the Colorado school district sued Moody's alleging that it had deliberately lowered its own bond ratings, and similarly, other issuers apparently feared that Moody's would arbitrarily lower their own credit ratings (White, 2010: 215-216).Therefore, it is understood that the criticisms made against the impartiality of CRAs are made not only from outside the USA, but also from those in their own countries where these CRAs are located. In terms of the objectivity of CRAs, researches on the rightness / injustice of these criticisms are important for countries. Because a country whose credit rating is unfairly lowered may face many negative situations such as current account deficit, inflation, economic contraction, decrease in exchange rate, foreign trade deficit.

\section{Credit Rating Agencies and Rating Systems}

Credit ratings used according to CRAs are ordinal scales that measure relative credit risk and are indicated by the rating symbol. High rated liabilities have lower credit risk than low rated liabilities.

The features of these rating scales are as follows:

- Arranged in a way that consists of letters and numbers (alpha-numeric).

- It aims to rank over a period.

- Consistent and comparable across instruments, maturities, sectors and countries

- It includes objective and transparency.

Ratings are about the lowest to highest estimation of the equipment/issuer, and investors can compare the ratings given by different rating agencies (Charumathi, 2017: 3-4). 
Credit rating agencies often provide different ratings for the same asset/company. The incompatibility between these organizations is more evident in measuring country ratings than in rating companies. In other words, these organizations were found to have different opinions. It has been suggested that there are three reasons for this incompatibility between organizations:

- Rating agencies use different factors and measure these factors with different weights.

- Rating agencies may largely disagree about issuers with more speculative ratings (country, company, etc.).

- Some rating agencies may have higher rating propensity for issuers (country, company, etc.) in their region. Regarding this last item, there are different opinions about whether the host country is the determining factor in determining the credit rating. For instance; it is argued that the higher ranking of issuers in the US than issuers outside of the US allows better estimation in the domestic market and the high-quality accounting information of the US (De Haan et al. 2011: 5).

The grading systems of the 3 credit rating agencies that provide different ratings to countries/institutions are shown in Table 3.

Table 3. Credit Rating System of Credit Rating Agencies

\begin{tabular}{|c|c|c|c|}
\hline Standart and Poors (S\&P) & Fitch & Moody's & Note Description \\
\hline \multicolumn{4}{|l|}{ Investable Level } \\
\hline AAA & AAA & Aaa & Highest Credit Rating \\
\hline $\mathrm{AA}+$ & $\mathrm{AA}+$ & Aa1 & \multirow{3}{*}{ High Credit Rating } \\
\hline AA & AA & $\mathrm{Aa} 2$ & \\
\hline AA- & AA- & Aa3 & \\
\hline $\mathrm{A}+$ & $\mathrm{A}+$ & A1 & \multirow{3}{*}{ Strong Payment Rating } \\
\hline A & A & $\mathrm{A} 2$ & \\
\hline A- & A- & A3 & \\
\hline $\mathrm{BBB}+$ & $\mathrm{BBB}+$ & Baa1 & \multirow{2}{*}{ Adequate Payment Rating } \\
\hline $\mathrm{BBB}$ & $\mathrm{BBB}$ & Baa2 & \\
\hline BBB- & BBB- & Baa3 & Ultimate Investment Level \\
\hline \multicolumn{4}{|l|}{ Speculative Level } \\
\hline $\mathrm{BB}+$ & $\mathrm{BB}+$ & Ba1 & \multirow{3}{*}{ Speculative Level } \\
\hline $\mathrm{BB}$ & $\mathrm{BB}$ & $\mathrm{Ba} 2$ & \\
\hline BB- & BB- & $\mathrm{Ba} 3$ & \\
\hline $\mathrm{B}+$ & $\mathrm{B}+$ & B1 & \multirow{3}{*}{ High Speculative Level } \\
\hline $\mathrm{B}$ & B & B2 & \\
\hline B- & B- & B3 & \\
\hline $\mathrm{CCC}+$ & $\mathrm{CC}+$ & Caa1 & \multirow{4}{*}{ High Bankruptcy Risk Rating } \\
\hline $\mathrm{CCC}$ & $\mathrm{CCC}$ & Caa2 & \\
\hline CCC- & CCC- & Caa3 & \\
\hline $\mathrm{CC}$ & $\mathrm{CC}$ & & \\
\hline \multicolumn{4}{|l|}{ Bankruptcy } \\
\hline C, D & C, D & $\mathrm{Ca}, \mathrm{C}$ & Degree of Failure to Fulfill its Obligation \\
\hline
\end{tabular}

When the grading system of the 3 major CRAs is examined, in order to be included in the investment grade category; should be in the range (AAA to BBB-) for S\&P and Fitch, and should be in the range (Aaa to Baa3) for Moody's. In other words, countries under the ratings BBB- and 
Baa3 are considered speculative and issuing bonds for investment seems very difficult. The + and - signs (in S\&P and Fitch) next to the credit ratings reveal the power difference between the countries' economies. In Moody's, the power difference between the countries' economies is revealed by the numbers 1,2 and 3 next to the credit ratings. For instance; the economy of a country with an AA rating is stronger than that of a country with an AA-rating, and the economy of a country with an Aa2 rating is stronger than that of a country with an Aa3 rating.

Likewise, while the 3 big CRAs are evaluating country credit ratings, they add positive, negative and stable expressions in parentheses besides the ratings, explaining their rating outlooks and specifying the possible future accelerations of the countries. For instance; it gives a clue that a country with a $\mathrm{BB}+$ (negative) rating will change its rating and its future rating will tend downward.

Credit rating agencies explain their rating systems in terms of local and foreign currency and short-long term. In the Global financial system, country ratings are generally expressed in longterm and foreign currency terms.

Balkan geography is important in many ways like political, economic, cultural, and so forth, for Turkey from the past to the present. Table 4 shows the credit ratings of the Balkan countries (according to S\&P; long-term and in foreign currency terms) and some important data (real growth rate, inflation rate, unemployment rate, current account balance/GDP, budget balance/GDP).

Table 4. Some Important Macro Economic Data with Credit Ratings of Balkan Countries $(2019)^{* *}$

\begin{tabular}{lllcccc}
\hline Countries & $\begin{array}{l}\text { Credit } \\
\text { Score } \\
\text { (S\&P) }\end{array}$ & $\begin{array}{l}\text { Real } \\
\text { Growth } \\
\text { Rate (\%) }\end{array}$ & $\begin{array}{l}\text { Inflation } \\
\text { Rate (\%) }\end{array}$ & $\begin{array}{l}\text { Unemployment } \\
\text { Rate (\%) }\end{array}$ & $\begin{array}{l}\text { Current } \\
\text { Balance/ } \\
\text { GDP (\%) }\end{array}$ & $\begin{array}{l}\text { Budget } \\
\text { Balance/ } \\
\text { GDP (\%) }\end{array}$ \\
\hline Albania & B + & 2.2 & 1.4 & 12.0 & -7.6 & -2.0 \\
\hline Bosnia-Herzegovina & B & 2.7 & 0.7 & 15.7 & -3.6 & 2.2 \\
\hline Bulgaria & BBB & 3.4 & 2.5 & 4.2 & 4.0 & -1.0 \\
\hline Croatia & BBB & 2.9 & 0.8 & 7.8 & 2.9 & 0.0 \\
\hline Montenegro & B + & 3.6 & 0.4 & - & -15.1 & -3.6 \\
\hline Macedonia & BB - & 3.6 & 0.8 & 17.3 & -2.8 & -2.0 \\
\hline Romania & BBB - & 4.1 & 3.8 & 3.9 & -4.7 & -4.6 \\
\hline Serbia & BB + & 4.2 & 1.9 & 10.9 & -6.9 & 0.0 \\
\hline Slovenia & AA - & 2.4 & 1.6 & 4.6 & 6.6 & 0.5 \\
\hline Turkey & B + & 0.9 & 15.2 & 13.7 & 1.1 & -5.3 \\
\hline Greece & BB - & 1.9 & 0.5 & 17.3 & -2.1 & 0.4 \\
\hline
\end{tabular}

**The Balkan countries that are the subject of the study; Albania, Bosnia and Herzegovina, Bulgaria, Croatia, Montenegro, Macedonia, Romania, Serbia, Slovenia, Turkey, Greece. Kosovo, which is one of the Balkan countries, is not included in the study because it is not rated by the three major credit rating agencies.

Source: IMF, 2020 Statistical Appendix: Tables Part A and Appendix Tables Part B; Unemployment Rate: https://www.imf.org/external/datamapper/LUR@WEO/OEMDC; https://countryeconomy.com/ratings

As in many countries, the objectivity of the decisions taken by the 3 major CRAs on the country rating is sometimes questioned. The failure to foresee the economic crises, the country's rating remaining unchanged despite the major negative developments in the US economy in the 2008 World economic crisis that emerged in the USA, the bankruptcy of large corporate companies such as Lehman Brothers and Enron, despite receiving good grades from CRAs, are some of the examples of the damage to the objectivity of CRAs. In addition, it is claimed that CRAs are managed by interest groups and their power is used as a pressure factor especially in 
developing countries. Against these criticisms, the establishment of a domestic CRA with a strong capital structure and broad vision can be a rational solution.

\section{Purposes and Possible Effects of Credit Rating}

External debt ratings by CRAs are widely used by market participants for a number of purposes. The most important of these are: (Table 5).

Table 5. Title, as well as the table, should be centered

Objectives for Investment and Risk Management

-Investing and making credit decisions

-Monitor and assess credit/counterparty risk

-Secure transfer of credit quality (bond issuers, borrowers)

-Appropriate determination of collateral (central bank and central counterparties)

- Risk informing and reporting

\begin{tabular}{c}
\hline Regulatory purposes (e.g. determining capital needs, monitoring systematic risk) \\
\hline Contractual purposes (e.g. access from capital markets to financial markets, etc.) \\
\hline Source: European Commission Final Report, 2015: 81.
\end{tabular}

Credit rating procedures by CRAs for countries/institutions may provide some benefits. The possible benefits to countries/institutions are as follows:

- It can increase your access to new markets.

- It can explain your creditworthiness to external parties.

- It can provide the opportunity to compare the strengths and weaknesses of your organization.

- It can increase your corporate transparency.

- It can help you estimate your cost of capital and create alternative strategies.

- It can provide information sharing to your partner when you create a joint venture.

- It can renew your performance by showing your credibility to investors.

- It can provide lower rental cost.

- It can play an important role in the infrastructure of the modern financial system.

- It can significantly increase both static and dynamic market efficiency by reducing the cost of information (Issuer Credit Ratings, https://www.spglobal.com/ratings/en/products-benefits/products/issuer-creditratings; Mählmann, 2006: 2).

Although many countries/companies around the world continue to receive services from credit rating agencies, there are also public criticisms of CRAs. We can collect these criticisms in 4 categories:

- Conflict of interest: The 'issuer pays' model has been the most important criticism focus of CRAs. There have been lawsuits in the past in the U.S. for the highest investment grades normally given to the safest corporate bonds due to fees charged to issuers of securities. 
- Lack of transparency: CRAs providing investment advice to the investor still rely on non-public information and personalized assessment methods. Therefore, the sector is faced with negativity between the personalized rating process and the evaluation process of investors and public employees. The lack of transparency invites problems about how firms deal with conflicts of interest. Transparency serves the public interest as long as it is wanted to be known about the rating.

- Lack of competence: It has been honestly stated by former S\&P executives that CRAs have been unfairly targeted by politicians, commentators and competitors, but that CRAs make technical mistakes in financial crises. It was agreed by others that CRAs used inadequate methodology to evaluate complex securities, and that CRAs were lacking in competence.

- Lack of competition in the sector: The 3 big CRAs own the majority of this sector. Although there are opinions that this situation creates economies of scale, it is argued that the concentration of the industry, which is formed by some segments, increases transparency and conflicts of interest. It is argued that the SEC implements policies that make entry into this sector more difficult and must find ways to encourage competition among CRAs. However, it is also argued that new entrants to the sector and increased competition will cause the rating scales to inflate (Scalet et al. 2012: 482-483).

In view of the strength and oligopolistic nature of the credit rating market, issuers have increasing cost concerns. Because the power of CRAs can lead to malicious practices such as issuers getting more additional services. In addition, CRAs have access to internal information that makes ratings more appropriate, and investors are concerned that they may give confusing signals to the markets because they lack this information (Pinto, 2006: 343-346).

Rating operations have increased, mostly due to the globalization of financial markets, with the use of credit ratings, the complexity of financial products, and generally increased use of financial regulation and rating in contracts. This increase in credit ratings was accompanied by an increase in the complexity of rating information. The information in the watch lists created by the rating agencies for the institutions they monitor has turned into tools that are used extensively to transfer this information to the financial markets (Bannier et al. 2010: 3037).

Credit rating determines not only whether a country is able to obtain affordable loans, but also whether it can attract other types of capital into the country. Countries with falling credit ratings need to rebuild their credibility by implementing policies to alleviate the concerns of potential creditors (Haque et al. 1997: 10).

Although the country rating is important for every country, it is especially important for underdeveloped/developing countries. Because the need for resources of countries with decreasing credit ratings is constantly increasing, and the need for borrowing is also increasing. Since developing countries generally have low ratings, these countries have difficulty in finding foreign debt, the country defaultswap (CDS) increases, and debts are taken at high interest rates. Therefore, it is vital that loans are used in investments (the golden rule). It is inevitable that a country that cannot use the borrowed debt in investments will encounter some negative options such as moratorium and consolidation. The end of a country faced with one of these negative options is to lower its credit rating again. 


\section{Credit Rating in Turkey}

It is the Capital Markets Board, which is responsible for rating activities in the capital markets in our country and is also one of the first institutions to emerge in the world. CMB, which issued the first communique on the rating activity in 1997, revised this communique on the axis of developments in the world, based on some international institutions, and introduced provisions to ensure that the rating activity is carried out independently and away from conflict of interest. (Communique on Principles Regarding Rating Activity and Rating Agencies in the Capital Markets, Series VIII, No: 51), which entered into force in the Official Gazette dated 12.07.2007 and numbered 26580.

Rating activity in the capital market covers the following 2 elements.

- Credit rating (is the activity of independent and fair evaluation and classification by rating agencies of the risk status and solvency of the enterprise or the ability to meet the principal, interest and similar liabilities of capital market instruments representing indebtedness)

- Corporate governance principles compliance rating (it is the activity of evaluating and classifying businesses/companies with the corporate governance principles determined by the Board in an impartial and fair manner by rating agencies (CMB, Rating Activity, http://www.spk.gov.tr)

It is the Capital Markets Board, which is responsible for rating activities in the capital markets in our country and is also one of the first institutions to emerge in the world. CMB, which issued the first communique on the rating activity in 1997, revised this communique on the axis of developments in the world, based on some international institutions, and introduced provisions to ensure that the rating activity is carried out independently and away from conflict of interest. (Communique on Principles Regarding Rating Activity and Rating Agencies in the Capital Markets, Series VIII, No: 51), which entered into force in the Official Gazette dated 12.07.2007 and numbered 26580.

Table 6. Title, as well as the table, should be centered

\begin{tabular}{|c|c|}
\hline $\begin{array}{l}\text { Rating Agencies Established in Turkey and } \\
\text { Authorized by the CMB }\end{array}$ & $\begin{array}{l}\text { International Rating Agencies Accepted by the } \\
\text { Board to Carry out Rating Activities in Turkey }\end{array}$ \\
\hline 1-DRC Rating Services Inc. & 1-Standards and Poors Global Rating Europe \\
\hline 2-Istanbul InternationalRating Services Inc. & 2-Moody's Investor Service Inc. \\
\hline 3- JCR Eurasia Rating Inc. & 3-Fitch Ratings Ltd. \\
\hline 4-Kobirate International Credit Rating and & \\
\hline Corporate Governance Services Inc. & \\
\hline 5-National Investor Services Rating Inc. & \\
\hline 6-Saha Corporate Governance and Credit Rating & \\
\hline Services Inc. & \\
\hline
\end{tabular}

Source: CMB, Authorized Institutions with Rating Activity, http://www.spk.gov.tr

Currently, credit rating procedures in Turkey are carried out by rating agencies established in Turkey and authorized by the Capital Markets Board, and by international rating agencies approved by the CMB to carry out rating activities in Turkey. Permitted rating agencies are divided into 2 categories and are listed in Table 6. 
Table 7. Development of Turkey's Credit Rating

\begin{tabular}{llll}
\hline Years & Standart and Poors (S\&P) & Fitch & Moody's \\
\hline 1992 & BBB (Stable) & & Baa3 \\
1994 & B + (Stable) & B & Ba3 \\
1995 & B + (Stable) & BB - & Ba3 \\
1996 & B (Stable) & B + & Ba3 \\
1997 & B (Stable) & B + & B1 \\
1998 & B (Positive) & B + & B1 \\
1999 & B (Positive) & B + & B1 (Positive) \\
2000 & B + (Stable) & BB - & B1 (Positive) \\
2001 & B - (Stable) & B (Negative) & B1 (Negative) \\
2002 & B - (Stable) & B (Stable) & B1 (Negative) \\
2003 & B + (Stable) & B (Positive) & B1 (Stable) \\
2004 & BB - (Stable) & B + (Positive) & B1 (Stable) \\
2005 & BB - (Stable) & BB - (Positive) & Ba3 (Stable) \\
2006 & BB - (Stable) & BB - (Positive) & Ba3 (Stable) \\
2007 & BB - (Stable) & BB - (Stable) & Ba3 (Stable) \\
2008 & BB - (Negative) & BB - (Stable) & Ba3 (Stable) \\
2009 & BB - (Stable) & BB + (Stable) & Ba3 (Positive) \\
2010 & BB (Positive) & BB + (Stable) & Ba2 (Positive) \\
2011 & BB (Positive) & BB + (Stable) & Ba2 (Positive) \\
2012 & BB (Stable) & BBB - (Stable) & Ba1 (Positive) \\
2013 & BB + (Stable) & BBB - (Stable) & Baa3 (Stable) \\
2014 & BB + (Negative) & BBB - (Stable) & Baa3 (Negative) \\
2015 & BB + (Negative) & BBB - (Stable) & Baa3 (Negative) \\
2016 & BB (Stable) & BBB- (Negative) & Ba1 (Stable) \\
2017 & BB (Negative) & BB + (Stable) & Ba1 (Negative) \\
2018 & B + (Stable) & BB (Negative) & Ba3 (Negative) \\
2019 & B + (Stable) & BB - (Stable) & B1 (Negative) \\
2020 & B + (Stable) & BB - (Negative) & B2 (Negative) \\
\hline & Sour Dat from &
\end{tabular}

Source: Data from 1992-2011 were taken from Mahfi Eğilmez

(http://www.mahfiegilmez.com/2017/01/turkiyenin-kredi-notu-nicin-dustu.html), 2012-2020 data were taken from T.C. Ministry of Treasury and Finance Public Debt Management Report (p.25). Our country's credit ratings show their final status at the end of each year.

When Turkey's credit rating evaluation process is examined in Table 7; for the first time in 1992, in the evaluation of ratings of S\&P and Moody's, it is seen that it has followed a fluctuating course until today. While our country, for which credit rating was made for the first time in 1992, was in the category of investment grade, it was out of the category of investable country right after the rating made in 1994.In general, the negative economic conjuncture (the rapid increase in domestic and foreign debt stock, excessively rising interest rates, the 1994 crisis due to budget and external deficits, the 1997 Southeast Asian crisis, the 1998 Russian crisis, and so forth.) had an effect. In addition, our country's credit rating remained at a low level in the early 2000s, due to the impact of the financial crises, which had a very negative impact on our country in November 2000 and February 2001.Although there was a partial improvement in our country rating in 2004 and later until the beginning of 2018, it is a speculative country for investments. Recently, our credit rating has been partially reduced. When looked at the historical process in general, although the credit ratings of the three big CRAs for our country are negative, Fitch's rating is more positive than S\&P and Moody's. 


\section{The Effect of Credit Ratings on Growth in Turkey and Balkan Countries}

\subsection{Material and Method}

In the study, the effect of credit ratings of 11 Balkan countries, including Turkey, on real growth was analyzed econometrically. All the data used in the analysis cover the period between 2008-2019 and all analyzes in the study were carried out with the E-views package program. The real growth rate, which was determined as the dependent variable, was obtained from the data bank of the World Bank, and the credit ratings, which were the independent variables, were obtained from three different credit rating agencies (Moody's, Fitch and S\&P). All data has been converted to Moody's grading system for consistency. Then, it was converted into a single numerical value range with $1=$ highest grade and $21=$ lowest grade and used. The conversion table is shown in Table 8.

Table 8. Credit Ratings Conversion Chart

\begin{tabular}{lllll}
\hline Rating & Moody's & S\&P & Fitch & Numerical Value \\
\hline The Highest & Aaa & AAA & AAA & 1 \\
\hline High & Aa1 & AA+ & AA+ & 2 \\
& Aa2 & AA & AA & 3 \\
& Aa3 & AA- & AA- & 4 \\
\hline High-Medium & A1 & A+ & A+ & 5 \\
& A2 & A & A & 6 \\
& A3 & A- & A- & 7 \\
\hline Low-Medium & Baa1 & BBB+ & BBB+ & 8 \\
& Baa2 & BBB & BBB & 9 \\
& Baa3 & BBB- & BBB- & 10 \\
\hline Significant Risks & Ba1 & BB+ & BB+ & 11 \\
& Ba2 & BB & BB & 12 \\
& Ba3 & BB- & BB- & 13 \\
\hline Quite Speculative & B1 & B+ & B+ & 14 \\
& B2 & B & B & 15 \\
& B3 & B- & B- & 16 \\
\hline Very High Risk & Caa1 & CCC+ & CCC+ & 17 \\
& Caa2 & CCC & CCC & 18 \\
& Caa3 & CCC- & CCC- & 19 \\
\hline Excessive Speculative & Ca & CC & CC & 20 \\
& & & C \\
\hline The Insolvency Threshold To Be Recovered & & SD & RD \\
Bankruptcy, Sunk & C & D & D & 21 \\
& & & DD & \\
\hline & & & DDD & \\
\hline
\end{tabular}

In addition, the inflation rate, unemployment rate, the ratio of the current account balance to the GDP and the ratio of the budget balance to the GDP were used as control variables in the study. All of these data were taken from the database of the World Bank. First, descriptive statistics were included in the analysis, and then Granger Causality Analysis was performed to test whether there was causality between the variables. The formula for causality analysis is as follows: 


$$
\begin{aligned}
& R E A L_{t}=\sum_{i=1}^{m} \alpha_{i} C R E_{t=1}+\sum_{i=1}^{m} \beta_{i} U R_{t=1}+\sum_{i=1}^{m} \theta_{i} I N F_{t=1}+\sum_{i=1}^{m} \gamma_{i} C A_{t=1}+\sum_{i=1}^{m} \delta_{i} B B_{t=1}+u_{t} \\
& C R E_{t}=\sum_{i=1}^{m} \varepsilon_{i} R E A L_{t=1}+\sum_{i=1}^{m} \beta_{i} U R_{t=1}+\sum_{i=1}^{m} \theta_{i} I N F_{t=1}+\sum_{i=1}^{m} \gamma_{i} C A_{t=1}+\sum_{i=1}^{m} \delta_{i} B B_{t=1}+u_{t} \\
& U R_{t}=\sum_{i=1}^{m} \varepsilon_{i} R E A L_{t=1}+\sum_{i=1}^{m} \alpha_{i} C R E_{t=1}+\sum_{i=1}^{m} \theta_{i} I N F_{t=1}+\sum_{i=1}^{m} \gamma_{i} C A_{t=1}+\sum_{i=1}^{m} \delta_{i} B B_{t=1}+u_{t} \\
& I N F_{t}=\sum_{i=1}^{m} \varepsilon_{i} R E A L_{t=1}+\sum_{i=1}^{m} \alpha_{i} C R E_{t=1}+\sum_{i=1}^{m} \beta_{i} U R_{t=1}+\sum_{i=1}^{m} \gamma_{i} C A_{t=1}+\sum_{i=1}^{m} \delta_{i} B B_{t=1}+u_{t} \\
& C A_{t}=\sum_{i=1}^{m} \varepsilon_{i} R E A L_{t=1}+\sum_{i=1}^{m} \alpha_{i} C R E_{t=1}+\sum_{i=1}^{m} \beta_{i} U R_{t=1}+\sum_{i=1}^{m} \theta_{i} I N F_{t=1}+\sum_{i=1}^{m} \delta_{i} B B_{t=1}+u_{t} \\
& B B_{t}=\sum_{i=1}^{m} \varepsilon_{i} R E A L_{t=1}+\sum_{i=1}^{m} \alpha_{i} C R E_{t=1}+\sum_{i=1}^{m} \beta_{i} U R_{t=1}+\sum_{i=1}^{m} \theta_{i} I N F_{t=1}+\sum_{i=1}^{m} \gamma_{i} C A_{t=1}+u_{t}
\end{aligned}
$$

In the last stage of the study, the real growth rate was determined as the dependent variable and the other series as the independent variable and panel data analysis was applied. There are two models in panel data analysis, fixed effects and random effects. The fixed effects model predicts that the starting point will take a different fixed value for all cross-section data. The random effects model defines the starting point as a random variable. If the assumptions of the random effects model are correct, both models give consistent results, but the results of the random effects model are more effective. If the assumptions of the random effects model are not valid, this model will yield inconsistent results (Balı and Cinel, 2011: 51). Which model to choose can be determined by the Hausman Test. The Hausman Test is used to evaluate the hypothesis that the error term components in the random effects model are not related to the independent variables. In this context, firstly, panel data analysis was made using both fixed effects and random effects models, and then it was decided which model to be used by performing the Hausman Test. The model used for analysis is as follows.

$$
R E A L_{i t}=\beta_{1}+\beta_{2} C R E_{2 i t}+\beta_{3} U R_{3 i t}+\beta_{4} I N F_{4 i t}+\beta_{5} C A_{5 i t}+\beta_{6} B B_{6 i t}+\varepsilon_{i t}
$$

Table 9. Explanations of Variables in Granger Causality and Panel Data Model

\begin{tabular}{ll}
\hline The Dependent Variable & The Independent Variable \\
\hline REAL: Real Growth Rate & CRE: Credit Score \\
& UR: Unemployment Rate \\
& INF: Inflation Rate \\
CA: Share of Current Account in GDP & BB: Share of Budget Balance in GDP
\end{tabular}

In the model used for panel data analysis, $\beta_{1}$ represents the constant coefficient and $\varepsilon_{i t}$ represents the error variable. The main hypotheses of the model were determined as follows: 
$H_{0}=$ There is no relationship between the independent variable and the dependent variable.

$H_{1}=$ There is a relationship between the independent variable and the dependent variable.

\subsection{Analysis}

In the first step of the analysis, descriptive statistics about the variables were included.

Table 10. Descriptive Statistics

\begin{tabular}{lllllll}
\hline & REAL & CRE & UR & INF & CA & BB \\
\hline Average & 1.928030 & 12.23485 & 15.36152 & 2.940909 & -5.30909 & -3.207576 \\
Median & 2.60000 & 13.00000 & 14.25000 & 2.000000 & -4.55000 & -2.800000 \\
Maximum & 11.10000 & 21.00000 & 33.80000 & 16.30000 & 6.60000 & 2.700000 \\
Minimum & -9.10000 & 3.000000 & 3.900000 & -1.60000 & -49.5000 & -15.10000 \\
Std. Deviation & 3.38610 & 3.053867 & 7.463894 & 3.496191 & 7.30517 & 2.990408 \\
Skewness & -0.72971 & -0.28343 & 0.477421 & 1.393741 & -2.06979 & -0.969543 \\
Kurtosis & 4.37783 & 4.504056 & 2.363552 & 4.990022 & 12.2141 & 5.396082 \\
Jarque-Bera & 22.15573 & 14.20937 & 7.242335 & 64.51632 & 561.198 & 52.25695 \\
Probability & 0.000015 & 0.000821 & 0.026751 & 0.000000 & 0.000000 & 0.000000 \\
Observation & 132 & 132 & 132 & 132 & 132 & 132 \\
\hline
\end{tabular}

In the second stage of the analysis, firstly, unit root test was applied to the series and it was determined that all series were second-order stationary. Second-order unit root tests are shown in Table 11.

Table 21. Second Order Unit Root Test

\begin{tabular}{lll}
\hline \multicolumn{3}{l}{ Series: Real Growth Rate } \\
\hline Method & Statistics & Probability \\
ADF - Fisher Chi-Square & 142.417 & 0.0000 \\
\hline Series: Credit Score & & \\
\hline Method & Statistics & Probability \\
ADF - Fisher Chi-Square & 80.3411 & 0.0000 \\
\hline Series: Unemployment Rate \\
\hline Method & Statistics & Probability \\
ADF - Fisher Chi-Square & 79.1507 & 0.0000 \\
\hline Series: Inflation Rate & Statistics & Probability \\
\hline Method & 114.888 & 0.0000 \\
\hline ADF - Fisher Chi-Square & \\
\hline Series: Current Balance \% GDP \\
\hline Method & Statistics & Probability \\
ADF - Fisher Chi-Square & 116.329 & 0.0000 \\
\hline Series: Budget Balance \% GDP \\
\hline Method & Statistics & Probability \\
ADF - Fisher Chi-Square & 123.491 & 0.0000 \\
\hline
\end{tabular}

After the unit root test, Granger causality analysis was performed to test whether there is causality between the variables. Analysis results are as in the tables below. 
Table 32. Granger Causality Analysis Results

\begin{tabular}{|c|c|c|c|c|c|c|c|}
\hline \multicolumn{2}{|c|}{ Variables } & \multirow{2}{*}{ Relation } & \multirow{2}{*}{ Observation } & \multicolumn{2}{|l|}{ F Statistics } & \multicolumn{2}{|c|}{ Probability Value } \\
\hline V1 & $\mathrm{V} 2$ & & & (V1-V2) & (V2-V1) & (V1-V2) & (V2-V1) \\
\hline CA & $\mathrm{BB}$ & - & 88 & 0,109369 & 0,015564 & 0,9468 & 0,9922 \\
\hline INF & $\mathrm{BB}$ & - & 88 & 2,057149 & 0,421233 & 0,3575 & 0,8101 \\
\hline INF & UR & $\rightarrow$ & 88 & 6,767321 & 3,824105 & 0,0339 & 0,1478 \\
\hline INF & REAL & $\rightarrow$ & 88 & 11,974830 & 2,302055 & 0,0025 & 0,3163 \\
\hline INF & $\mathrm{CA}$ & $\leftrightarrow$ & 88 & 12,420520 & 10,348300 & 0,0020 & 0,0057 \\
\hline UR & $\mathrm{BB}$ & - & 88 & 0,980961 & 0,581730 & 0,6123 & 0,7476 \\
\hline UR & CA & - & 88 & 0,793516 & 3,941462 & 0,6725 & 0,1394 \\
\hline UR & REAL & $\rightarrow$ & 88 & 8,022057 & 2,970512 & 0,0181 & 0,2264 \\
\hline CRE & $\mathrm{BB}$ & - & 88 & 2,944796 & 0,837736 & 0,2294 & 0,6578 \\
\hline CRE & CA & - & 88 & 4,840385 & 0,110059 & 0,0889 & 0,9465 \\
\hline CRE & INF & - & 88 & 0,968710 & 5,365613 & 0,6161 & 0,0684 \\
\hline CRE & UR & $\leftrightarrow$ & 88 & 8,420282 & 7,350655 & 0,0148 & 0,0253 \\
\hline REAL & CA & - & 88 & 5,498679 & 2,696634 & 0,0640 & 0,2597 \\
\hline REAL & CRE & - & 88 & 0,196691 & 2,853753 & 0,9063 & 0,2401 \\
\hline REAL & $\mathrm{BB}$ & $\rightarrow$ & 88 & 8,734831 & 2,605483 & 0,0127 & 0,2718 \\
\hline \multicolumn{8}{|c|}{ - no relation } \\
\hline \multicolumn{8}{|c|}{$\rightarrow \mathrm{V} 1$ is the cause of $\mathrm{V} 2$} \\
\hline \multicolumn{8}{|c|}{$\leftrightarrow$ there is mutual causation } \\
\hline
\end{tabular}

When Table 12 is analyzed, it is seen that there is a mutual causality between unemployment and credit score, and between current account balance and inflation. In addition, inflation is the cause of unemployment and real growth; and also it has been determined that unemployment is the cause of the real growth. In addition, according to the results of the analysis, real growth is seen as the reason for the budget balance.

Table 43. Panel Data Analysis Results with Fixed and Random Effects Model

\begin{tabular}{lllllll}
\hline Dependent Variable: REAL & \multicolumn{3}{c}{ Fixed Effects } & \multicolumn{3}{c}{ Random Effects } \\
\hline Independent variables & Parameter & t-Statistics & Prob. & Parameter & t-Statistics & Prob. \\
\hline CRE & $-1,220022$ & $-2,906614$ & 0,0046 & $-1,205847$ & $-2,883948$ & 0,0048 \\
UR & 0,571420 & 1,423004 & 0,1580 & 0,572218 & 1,430741 & 0,1555 \\
INF & 0,348446 & 2,315601 & 0,0228 & 0,345358 & 2,309811 & 0,0229 \\
CA & $-0,347238$ & $-2,413127$ & 0,0178 & $-0,343069$ & $-2,416183$ & 0,0174 \\
BB & 0,436081 & 2,771909 & 0,0067 & 0,434752 & 2,767606 & 0,0067 \\
\hline R square & & 0,242755 & & & 0,238813 & \\
Corrected R Square & & 0,121918 & & & 0,202217 & \\
Probability (F-statistics) & & 0,022342 & & & 0,000026 & \\
Durbin-Watson & 2,759747 & & & 2,742602 & \\
\hline
\end{tabular}

According to the results of both fixed and random effects model of the Panel data analysis seen in Table 13, $H_{0}$ hypothesis is rejected for credit score, inflation, current account balance and budget balance, and $H_{1}$ hypothesis is accepted. In other words, credit score, inflation, current 
account balance and budget balance are effective on real growth. However, since the probability value for unemployment is not significant, the $H_{0}$ hypothesis is accepted, that is, there is no relationship between unemployment and real growth. Additionally, it is observed that the coefficient of credit score and current account balance is negative. Here, the fact that the credit score moves in the opposite direction according to other variables, with $1=$ the best 21 = the worst, causes the coefficient to be negative.

Finally, by performing the Hausman Test, it is determined whether the fixed effects model or the random effects model will be used. The hypotheses created for the test are as follows:

$H_{0}$ : There are random effects

$H_{1}$ : No random effects.

Table 54. Hausman Test

\begin{tabular}{lccc}
\hline Test Summary & Chi-Square Statistics & $\begin{array}{l}\text { Chi-Square } \\
\text { Degree of Independence }\end{array}$ & Probability \\
\hline Cross-section random & 0.197331 & 5 & 0.9991 \\
\hline
\end{tabular}

As a result of the Hausman Test, since the probability value observed in Table 14 is $>0.05$, that is, meaningless according to the $5 \%$ significance level, the $H_{0}$ hypothesis is accepted and it is determined that the random effects model will be taken into account.

\section{Conclusion}

Credit rating agencies with a history of more than a century have started to gain importance with the development of capital markets. Countries/firms need reliable information in a world that has become more complex due to the increase in financial capital movements. One of the aims of CRAs, which aim to meet this need, is to reduce the information asymmetry between the groups involved in the borrowing process.

In particular, the decisions taken by Standard and Poors, Moody's and Fitch, which are popular as the 3 big CRAs, affect the economic and financial structure of those countries positively or negatively. For example; When a public rating agency evaluates the country with a low score, it increases the borrowing cost of the country and makes it difficult for it to borrow from foreign markets.

At the same time, it makes it difficult for foreign capital to enter the relevant country, leads to distrust, discourages investors, and consequently reduces the economic growth. The independence of the decisions taken by the CRAs is also frequently discussed by the public.

Against the problems experienced, some solution suggestions can be developed to reduce the criticisms towards CRAs/eliminate the problems. Solution suggestions are as follows:

- Basing the evaluation criteria of the three major CRAs on objective measures as much as possible.

- Making the methodology applied by these organizations transparent and making it public

- Revision of the 'issuer pays' model in order to avoid conflicts of interest that might arise

- Taking measures to break the oligopoly structure of the three big CRAs, creating alternative CRAs

- To take measures to facilitate the entry of new companies in order to open the sector to competition and to carry out legislative studies in this direction. 
- Good functioning of the accountability mechanism, having a sanction mechanism for CRAs that make wrong decisions/execute policies

- More effective surveillance and supervision of CRAs

- Conducting studies to ensure that CRA employees act in accordance with professional ethics.

As a result of the analysis made in our study, the scores given to the countries by the credit rating agencies have been determined to be effective on economic growth. The reason for this is that credit scores are accepted as a reference for investments in countries. Investors invest in countries taking into account their credit scores, and this ensures the economic growth. At this point, countries need to take steps to keep their credit scores high in order to attract more investments and strengthen their economies.

In addition, it has been determined that rising inflation causes economic growth in selected countries. In the literature, this phenomenon finds its place under the name of "inflationary growth". Inflationary growth occurs when inflation remains high or grows while economies are growing. The most common reason for this situation to occur is economies dependent on high imported inputs. The reflection of the increase in exchange rates causes an increase in costs. At this point, it plays a vital role in attracting investors, namely foreign currency to the country. Because it is an economically generally accepted rule that the value of the exchange rate will decrease as the foreign exchange inflow to the country increases.

The negative effect of the current account balance on real growth is thought to be due to the "growth model by giving current account deficit", which has also taken its place in the literature. In most of the developing countries, the high level of production with imported inputs deteriorates the current account balance, but affects growth positively. In this way, the decrease in the current account balance, that is, the increase in the current account deficit, causes an increase in economic growth. Finally, the positive effect of the budget balance on growth emerges as an expected result. At this point, the steps taken to close the budget deficits, such as foreign borrowing, domestic borrowing, coinage, increasing public services and increasing taxes are of great importance. Because these steps are of the nature to increase inflation and current account deficit. The fact that the increase in these variables, which was mentioned before, causes growth, leads to the conclusion that the increase in the budget balance also increases the growth.

With the disappearance of borders in the globalizing world, the structure of institutions has become quite complex. CRAs; collects information about local/national institutions, general/special financial instruments, converts this information into specific letters, and provides financial consultancy services to countries/institutions. Therefore, although there are criticisms on the agenda of the countries, it seems that CRAs will continue to be an important part of the financial structure with their expertise. The fact that the data of the countries determined for the study covers an 11-year period, limits the use of different analysis methods in the study. With the increase in data in the following years, it is aimed to expand the current study with methods such as ARDL that measure short and long-term effects.

\section{References}

Balı, S. \& Cinel, M.O. (2011). Altın Fiyatlarının İmkb 100 Endeksi'ne Etkisi ve Bu Etkinin Ölçümlenmesi. Atatürk Üniversitesi İktisadi ve İdari Bilimler Dergisi, 25(3-4), 45-63.

Bannier, C.E., \& Christian W. (2010). The Economic Function of Credit Rating Agencies-What Does the Watchlist Tell Us?. Journal of Banking \& Finance, 34 (12), 3037-3049. 
Becker, B., \& Milbourn, T. (2011). How Did Increased Competition Affect Credit Ratings? Journal of Financial Economics, 101 (3), 493-514.

Bhatia, A. V. (2002). Sovereign Credit Ratings Methodology: An Evaluation. IMF Working Paper, No. 02/170.

Bjørndalen, F.A., Høgheim, V., Nilsson, J., Svensson, M. (2014). The Power of Credit Ratings -A Study of Credit Ratings Changes' Effects on Essential Firm Aspects. Lund University School of Economics and Management, Sweden.

Charumathi, B. (2017). Need for Uniform Rating Scales Across all Rating Agencies. Journal of Internet Banking Commerce, 22 (3), 1-20.

De Haan, J., \& Amtenbrink, F. (2011). Credit Rating Agencies. De Nederlandsche Bank Working Paper, No. 278.

European Commission (2015). Study on the Feasibility of Alternatives to Credit Ratings Final Report.

Friedman, T.L., Foreign Affairs; Don't Mess with Moody's, 22 February 1995, https://www.nytimes.com/1995/02/22/opinion/foreign-affairs-don-t-mess-with-moodys.html, (date accessed: 01.11.2020).

Haque, N.U., Mathieson, D., \& Mark, N. (1997). Rating the Raters of Country Creditworthiness. Finance \& Development, 10-13.

IMF. (2020). World Economic Outlook, Growth Slowdown, Precarious Recovery, April 2020 Statistical Appendix: Tables Part A; Appendix Tables Part B, Washington D.C.

Issuer Credit Ratings, https://www.spglobal.com/ratings/en/products-benefits/products/issuercredit-ratings, (date accessed: 03.10.2020).

Langohr, H. \& Langohr, P. (2008). The Rating Agencies and Their Credit Ratings: What They Are, How They Work, and Why They Are Relevant. A John Wiley and Sons Ltd. Publication.

Levich, R.M., Majnoni, G. \& Reinahart, C. M. (2002). Introduction: Ratings, Rating Agencies and The Global Financial System: Summary and Policy Implications. The New York University Salomon Center Series on Financial Markets and Institutions Book Series, 115.

Mählmann, T. (2006). Do Bond Issuers Shop for A Better Credit Rating. Department of Banking, University of Cologne, Koeln Germany.

Mullard, M. (2012). The Credit Rating Agencies and Their Contribution to the Financial Crisis. The Political Quarterly, 83 (1), 77-95.

Pinto, A.R. (2006). Control and Responsibility of Credit Rating Agencies in the United States. The American Journal of Comparative Law, American Law in the 21st Century: U.S. National Reports to the XVII the International Congress of Comparative Law, (54): 341-356.

Rating Definitions, Fitch, https://www.fitchratings.com/site/definitions, date accessed: 08.10.2020).

Rating Symbols and Definitions, Moody's Investor Services, www.moodys.com, (date accessed: 07.10.2020).

S\&P Global Rating Definitions, Standart and Poors, June 26, 2017. https://www.standardandpoors.com/en_EU/delegate/getPDF?articleId=2017758\&type= COMMENTS\&subType=REGULATORY, (date accessed: 14.09.2020). 
Scalet, S. \& Kelly, T. F. (2012). The Ethics of Credit Rating Agencies: What Happened and the Way Forward. Journal of Business Ethics, 111 (4), 477-490.

Sinclair, T. J. (2003). Global Monitor Bond Rating Agencies. New Political Economy, 8 (1), 147161.

Sovereigns Ratings List, https://countryeconomy.com/ratings (date accessed: 12.09.2020).

SPK, http://www.spk.gov.tr, (date accessed: 09.09.2020).

Sylla, R. (2002). A Historical Primer on the Business of Credit Ratings. Department of Economics, Stern School of Business.

Hazine T.C., Bakanlığı, M. (2021). Kamu Borç Yönetimi Raporu, No. 185. February 2021, Ankara.

Tennant, D.F. \& Tracey, M.R. (2016). Credit Rating Agencies as Gatekeepers. In Book: Sovereign Debt and Credit Bias, 1-14.

The US Should Let Its Credit Rating Be Downgraded-and Shrug," https://www.theguardian.com/commentisfree/cifamerica/2011/aug/05/us-credit-ratingdowngraded-moodys, (date accessed: 12.10.2020).

Türkiye'nin Kredi Notu Neden Düştü?, http://www.mahfiegilmez.com/2017/01/turkiyeninkredi-notu-nicin-dustu.html, (date accessed: 24.11.2020).

U.S. Securities and Exchange Commission (December 2020), Annual Report on Nationally Recognized Statistical Rating Organizations.

Unemployment Rate: https://www.imf.org/external/datamapper/LUR@WEO/OEMDC (date accessed: 28.12 .2020 )

United Nations (2008). Conference on Trade and Development Discussion Papers, Credit Rating Agencies and Their Potential Impact on Developing Countries, No.186.

United Nations (2009). United Nations Conference on Trade and Development, Compendium on Debt Sustainability and Development.

White, L.J. (2010). Markets the Credit Rating Agencies. Journal of Economic Perspectives, 24(2), 211-226.

12.07.2007 tarihli ve 26580 sayılı Resmi Gazete'de Yürürlüğe Giren " Sermaye Piyasasında Derecelendirme Faaliyeti ve Derecelendirme Kuruluşlarına İlişkin Esaslar Tebliği" Vol. VIII, No: 51.

(C) 2021 by the authors. Submitted for possible open access publication under the terms and (i) conditions of the Creative Commons Attribution (CC BY) license (http://creativecommons.org/licenses/by/4.0/). 